\title{
PENYULUHAN PEMBERDAYAAN KOPERASI SEBAGAI SARANA PENINGKATAN EKONOMI WARGA RW.04 SEKTOR III BUMI PUSPIPTEK ASRI PAGEDANGAN KABUPATEN TANGERANG
}

\author{
D Sunardi, AM Irfanudin, Syam Budi, D Hendra, I Jamil \\ Universitas Pamulang \\ Email:dosen00724@unpam.ac.id
}

\begin{abstract}
This community service activity aims to transfer knowledge on how to increase the empowerment of community businesses in order to improve the community's economy by integrating every activity of consumption, production and businesses carried out by its citizens. So that from this activity it is formed or has a legal form or legal entity. With the formation of the cooperative, it is hoped that the production, trade, and consumption businesses carried out by the community in RW.04 Sector III Bumi Puspiptek Asri (BPA) Pagedangan Village can develop and in the end can increase community income. The results showed that prior to the implementation of PKM, the community members in RW.04 Sector III BPA, had not formally formed a cooperative, and efforts carried out using manual and trading systems were not familiar with terms related to product marketing through online media (online), however, after carrying out the activity, it was known that the residents of RW.04 Sector III BPA could understand the basics of forming a cooperative, marketing products through social media. PKM activities play a positive role in increasing the knowledge and skills of participants in understanding cooperatives and selling via online media. The activity method used is to collaborate with the residents of RW.04 Sector III BPA, whose address is RW.04 Perumahan Bumi Puspiptek Asri Sector III, Pagedangan Village, Tangeranga Regency and looking for problems in that place so that they can provide the right solution to motivate Community members are business actors in Pagedangan Village, especially residents of RW.04 Sector III BPA. After the analysis, we provide training in the form of materials and practices that aim to develop the ability to increase marketing via online media for residents of $R W .04$ Sector III BPA, Pagedangan Village.
\end{abstract}

Keywords: Cooperative, Sales, Online Media

\begin{abstract}
Abstrak
Kegiatan pengabdian kepada masyarakat ini bertujuan untuk mentransfer pengetahuan bagaimana cara meningkatkan pemberdayaan usaha-usaha masyarakat agar dapat meningkatkan perekonomian masyarakat dengan cara mengintegrasikan setiap kegiatan konsumsi, produksi dan usaha-usaha yang dilakukan oleh warganya. Sehingga dari kegiatan ini terbentuk atau memiliki bentuk atau badan hukum yang legal. Dengan terbentuknya koperasi diharapkan usaha produksi, perdagangan, maupun konsumsi yang
\end{abstract}


dilakukan masyarakat di RW.04 Sektor III Bumi Puspiptek Asri (BPA) Desa Pagedangan dapat berkembang dan pada akhirnya dapat meningkatkan pendapatan masyarakat. Hasil kegiatan menunjukkan bahwa sebelum pelaksanaan PKM, para warga masyarakat di RW.04 Sektor III BPA, belum terbentuk koperasi secara formal, dan usaha-usaha yang dilakukan menggunakan sistem manual dan pedagangan belum mengenal istilah-istilah terkait dengan pemasaran produk lewat media daring (online), namun setelah pelaksaan kegiatan diketahui para warga RW.04 Sektor III BPA dapat memahami dasar-dasar pembentukan koperasi, pemasaran produk melalui media sosial. Kegiatan PKM berperan positif dalam meningkatkan pengetahuan dan keterampilan peserta dalam memahami koperasi dan penjualan lewat media online. Metode kegiatan yang digunakan adalah bekerjasama dengan ibu-ibu Warga RW.04 Sektor III BPA, yang beralamat di RW.04 Perumahan Bumi Puspiptek Asri Sektor III Desa Pagedangan Kabupaten Tangeranga dan mencari pemasalahan yang ada di tempat tersebut sehingga dapat memberikan solusi yang tepat dalam memotivasi warga masyarakat adalah pelaku bisnis di Desa Pagedangan khususnya warga RW.04 Sektor III BPA. Setelah di analisis maka kami memberikan pelatihan dalam bentuk materi dan praktek ayng bertujuan mengembangkan kemampuan untuk meningkatkan pemasaran via media daring (online) bagi para warga RW.04 Sektor III BPA Desa Pagedangan.

Kata Kunci: Koperasi, Penjualan, Media Online

\section{A. PENDAHULUAN}

Memasuki ekosistem industri 4.0 menuntut para pelaku bisnis di Indonesia untuk terus melakukan pengembangan-pengembangan di setiap lini. Hal ini secara sadar maupun tidak membawa kita manusia Indonesia untuk semakin 'melek' terhadap teknologi. Kenyataannya saat ini masih banyak kalangan pelaku industri mulai dari kalangan UMKM dan yang setara dengannya kurang menyadari prospek dan peluang yang diberikan melalui media komunikasi internet atau media digital. Bicara mengenai kualitas produk ataupun jasa, sebetulnya produk maupun jasa dalam negeri tidak kalah dibanding produk-produk impor. Hal ini diperparah budaya konsumtif masyarakat yang lebih bangga menggunakan produk branded luar dibanding produk asli Indonesia.

Pembekalan edukasi terkait dengan penggunaan fasilitas internet, terlebih terkait membangun bisnis sangat diperlukan oleh masyarakat, khususnya para pelaku usaha kecil dan menengah agar dapat bersaing, memperkenalkan produk atau jasa mereka dengan metode yang baru agar mendapat pasar yang maksimal. Untuk itu, kami selaku tim pengabdi berinisiatif untuk berbagi pengetahuan berkaitan dengan pemasaran digital.

Untuk memberikan pengetahuan baru mengenai bagaimana cara memasarkan produk via internet, mengenal beberapa istilah dalam bisnis online, mempromosikan produk dan metode-metode yang dapat dilakukan dengan harapan menjadi rintisan usaha yang kompetitif dan berdaya saing.

Dalam memasarkan produk, biasanya para pelaku usaha di kalangan warga RW.04 Sektor III BPA, menggunakan media konvensional, memasarkan produk langsung ke pelanggan, promosi dari anggota ke anggota maupun ke warga sekitar, yang dianggap masih kurang maksimal dalam memperoleh keuntungan, dan ini dilakukan dikalangan anggota kelompok usaha masyarakat yang belum terorganiisr dengan baik/ terbentuk dalam koperasi. Mereka warga sektor III BPA berkelompok dalam mengumpulkan dana dan berusahan secara 
bersama namun belum secara formal seperti koperasi. Dan dalam pemasaran produk dari warga masyarakat RW.04 Sektor III BPA masih menggunakan manual sehingga pemasaran produk sangat terbatas.

Dari data warga RW.04 sektor III BPA yang berwirausaha atau memiliki usaha kecil menengah, masih kurangnya pengetahuan mengenai cara memasarkan produk dan jasa dengan efektif dan mendapat traffic yang tinggi. Dan mereka berkelompok mendirikan kelompok usaha namun belum membentuk koperasi. Melihat kenyataan ini perlu dan mendesaknya kebutuhan, maka dirasa perlu adanya pelatihan dan penyuluhan mengenai pendiriian koperasi dan penyuluhan mengenai pemasaran produk lewat media online, guna meningkatkan kompetensi dan pemahaman mereka.

Untuk itu, kami Dosen Universitas Pamulang dan Yayasan Sasmita Jaya dan mahasiswa mengadakan Pengabdian Kepada Masyarakat (PKM) bekerjasama dengan Warga RW.04 Sektor III Peruamahan Bumi Puspiptek Asri Desa Pagedangan memberikan pelatihan dengan tema "Penyuluhan Pemberdayaan Koperasi Sebagai Sarana Peningkatan Ekonomi Warga RW.04 Sektor III Bumi Puspiptek Asri Pagedangan Kabupaten Tangerang”.

\section{B. METODE PELAKSANAAN KEGIATAN}

Permasalahan yang dihadapi warga komplek/perumahan puspiptek pagedangan adalah belum adanya suatu badan pemberdayaan yang secara keseluruhan mengintegrasikan setiap kegiatan konsumsi, produksi dan usaha-usaha yang dilakukan oleh warganya. Kegiatan yang saat ini telah berlangsung terkait dengan peningkatan ekonomi warga belum memiliki bentuk atau badan hukum yang legal. Dengan terbentuknya koperasi diharapkan usaha produksi, perdagangan, maupun konsumsi yang dilakukan masyarakat di komplek puspiptek pagedangan dapat berkembang dan pada akhirnya dapat meningkatkan pendapatan masyarakat.

Koperasi dipahami sebagai badan hukum yang didirikan berdasar asas kekeluargaan. Menganut prinsip ekonomi kerakyatan, dibentuknya sebuah koperasi bertujuan untuk mensejahterakan para anggotanya. Jadi, seluruh keuntungan yang didapat oleh koperasi akan dikelola untuk kemajuan kinerja koperasi dan dibagikan pada anggota aktif. Siapapun dapat mendirikan sebuah koperasi, baik perorangan maupun badan hukum. Modal dari usaha koperasi ini didapat dari seluruh anggotanya, sehingga jalannya usaha ini harus menyesuaikan aspirasi serta kebutuhan bersama. Kata koperasi diambil dari Bahasa Inggris, co-operation yang berarti kerja sama. Jadi sistem pengelolaan koperasi didasarkan pada asas kekeluargaan dan kehidupan berdemokrasi.

Solusi yang diberikan terhadap Permasalahan Mitra yang merupakan Warga puspiptek pagendangan serpong Tangsel adalah dengan memberikan penyuluhan tentang bagaimana membedayakan kegiatan peningkatan ekonomi melalui pembentukan Koperasi sebagai wadah yang mengintegrasikan segala bentuk kegiatan masyarakat di wilayah pagedangan.

Kami selaku dosen program studi Manajemen S1 dan Akuntansi S1 memberikan input atau masukan kepada mitra yang adalah Rukun Warga Komplek Puspiptek Pagedangan, Serpong, Tangerang Selatan untuk dapat mengimplementasikan baik secara teori maupun secara praktik mengenai pengembangan usaha melalui koperasi sebagai suatu badan hukum berasas kekeluargaan dan berkehidupan berdemokrasi.

Berikut adalah beberapa point yang kami rumuskan sebagai solusi untuk permasalahan yang dihadapi mitra warga puspiptek pagedangan serpong tangsel:

1. Memberikan pengetahuan tentang pentingnya koperasi bagi warga sekaligus produsen dari berbagai produk (multi-produksi) di Komplek Puspiptek Pagedangan Serpong

2. Meningkatkan kesadaran warga di Komplek Puspiptek Pagedangan Serpong akan pentingnya koperasi, 
3. Terbentuknya koperasi serba usaha (KSU) yang dibutuhkan masyarakat, yang dapat memfasilitasi segala kegiatan (termasuk didalamnya Perdagangan, produksi, simpan pinjam, konsumsi) di Komplek Puspiptek Pagedangan Serpong

4. Meningkatkan produksi dan terciptanya kontinuitas produksi serta meningkatnya pendapatan masyarakat Komplek Puspiptek Pagedangan Serpong dengan terbentuknya koperasi.

Berikut ini adalah tahapan pelatihan yang dilakukan:

1. Tahap persiapan, Tahap persiapan yang dilakukan meliputi:

a. Survey awal,

b. Pemantapan dan penentuan lokasi dan sasaran. Setelah survey maka ditentukan lokasi pelaksanaan dan sasaran peserta kegiatan.

2. Tahap Pelaksanaan Pengabdian Kepada Masyarakat

Tahap ini akan diberikan penjelasan mengenai dasar-dasar serta legalitas pendirian Koperasi Serba Usaha

3. Tahap Pelatihan

Untuk melaksanakan kegiatan tersebut digunakan beberapa metode pelatihan yaitu:

a. Metode ceramah

b. Metode tanya jawab

\section{HASIL DAN PEMBAHASAN}

Dari hasil survey dan wawancara bersama perwakilan warga RW 04 Sektor III BPA, bahwa permasalahan yang ada sekarang ini dan masih berlanjut salah satunya yaitu Dalam memasarkan produk, biasanya para pelaku usaha di kalangan warga RW.04 Sektor III BPA, menggunakan media konvensional, memasarkan produk langsung ke pelanggan, promosi dari anggota ke anggota maupun ke warga sekitar, yang dianggap masih kurang maksimal dalam memperoleh keuntungan, dan ini dilakukan dikalangan anggota kelompok usaha masyarakat yang belum terorganiisr dengan baik/ terbentuk dalam koperasi. Mereka warga sektor III BPA berkelompok dalam mengumpulkan dana dan berusahan secara bersama namun belum secara formal seperti koperasi. Dan dalam pemasaran produk dari warga masyarakat RW.04 Sektor III BPA masih menerapkan cara tradisional sehingga pemasaran produk sangat terbatas.

Dari data warga RW.04 sektor III BPA yang berwirausaha atau memiliki usaha kecil menengah, masih kurangnya pengetahuan mengenai cara memasarkan produk dan jasa dengan efektif dan mendapat traffic yang tinggi. Dan mereka berkelompok mendirikan kelompok usaha namun belum membentuk koperasi. Melihat kenyataan ini perlu dan mendesaknya kebutuhan, maka dirasa perlu adanya pelatihan dan penyuluhan mengenai pendiriian koperasi dan penyuluhan mengenai pemasaran produk lewat media online, guna meningkatkan kompetensi dan pemahaman mereka.

Adapun tahapan dalam merealisasikan kegiatan tersebut adalah dimulai dengan bekerjasama dengan memberikan penyuluhan serta pelatihan secara singkat dan terbatas mengenai dasar dasar pendirian Koperasi, Legalitas, serta dasar payung hukumnya. Serta dalam konteks pemasaran produk dari warga masyarakat RW.04 Sektor III BPA, penggunaan media sosial sebagai alternatif dan ekspansi (perluasan) bisnis ke arah digital sehingga memberikan jumlah pasar yang lebih luas dan cakupan yang lebih besar. Dengan berbekal pengetahuan berupa pemasaran produk melalui media digital, harapannya kedepan para Warga lebih dapat memaksimalkan penjualan produk atau jasa yang selama ini mereka telah dilakukan melalui media konvensional. Serta menambah pendapatan warganya terlebih dalam menghadapi kondisi dan situasi yang tidak menentu saat ini. 


\section{KESIMPULAN DAN SARAN}

\section{Simpulan}

Pelaksanaan kegiatan Pengabdian Kepada Masyarakat oleh Lembaga Penelitian dan Pengabdian Masyarakat (LPPM) Universitas Pamulang yang dilakukan oleh dosen-dosen program studi Manajemen telah berjalan dengan lancar dan mendapat sambutan hangat dari tempat pelaksanaan kegiatan ini yaitu Ketua RW.04 Sektor III BPA. Harapan kami dengan pengabdian ini dapat menambah ilmu yang bermanfaat dalam Penyuluhan Pemberdayaan Koperasi Sebagai Sarana Peningkatan Ekonomi Warga RW.04 Sektor III Bumi Puspiptek Asri Pagedangan Kabupaten Tangerang.

\section{Saran}

Berdasarkan hasil kegiatan Pengabdian Kepada Masyarakat, maka kami dari Tim Dosen Universitas Pamulang memberikan saran diantaranya sebagai berikut:

1. Karena pengetahuan dan disiplin ilmu terkait pelaksanaan dan pendirian Koperasi, banyak alternatif lain yang dalam membantu pelaksanaannya, maka kegiatan ini baiknya tidak hanya dilaksanakan satu kali saja, diharapkan ada kegiatan lainnya, agar para peserta penyuluhan dari Warga RW 04 Sektor III BPA menambah pengetahuan dan bisa memahami secara menyeluruh.

2. Fasilitas yang digunakan oleh Dosen Dosen UNPAM yang melakukan pelatihan sangat sederhana, diharapkan dari pihak kampus, meberikan fasilitas agar proses pembelajaran lebih efektif.

\section{Ucapan Terima Kasih}

Rasa syukur dan suka cita kamu haturkan kepada segenap pihak yang telah mensukseskan kegiatan PKM dengan judul "Penyuluhan Pemberdayaan Koperasi Sebagai Sarana Peningkatan Ekonomi Warga Rw.04 Sektor III Bumi Puspiptek Asri Pagedangan Kabupaten Tangerang" kepada:

1. Rektor Dr. H. Dayat Hidayat, M.M, Rektor Universitas Pamulang Tangerang Selatan Banten.

2. Dr. Ali Maddinsyah, S.E., M.M., selaku Ketua LPPM Universitas Pamulang Tangerang Selatan - Banten.

3. Dr. Kasmad, S.E., M.,M., selaku Ketua Program Studi Manajemen Universitas Pamulang Tangerang Selatan - Banten.

4. Dr. Udin Ahidin, S.E., M.M., C.M.A, Selaku Wakil Program Studi Manajemen Universitas Pamulang Tangerang Selatan - Banten.

5. Drs. Waluyo Jati, M.M., Selaku Sekretaris Program Studi Manajemen Universitas Pamulang Tangerang Selatan - Banten.

6. Para Warga RW 04 Sektor III Bumi Puspitek Asri, atas kesempatannya dalam pelaksanaan Pengabdian Masyarakat periode ini.

\section{DAFTAR PUSTAKA}

AM Irfanudin, D Sunardi, R Sari, I Imbron, N Nariah. (2020). PERAN SEO DALAM MENINGKATKAN RELIABILITAS PEMASARAN PRODUK VIA MEDIA ONLINE PADA FORUM MUSLIMAH DEPOK. Dedikasi PKM, 1(1) 
AM Irfanudin, E Kurniawati, Jamaluddin, R Andalusi, Noryani. (2020). STRATEGI BERBISNIS ONLINE DITENGAH PANDEMI CORONA VIRUS DISEASE 2019 COVID-19. Dedikasi PKM, Vol.1(2)

Tahapan Pendirian Koperasi, https:/tirto.id/tahapan-pendirian-koperasi-dan-syaratpengesahan-badan-hukumnya-ekom , diakses pada: 25 Desember 2020

Kasali, R., \& dkk. (2010). Modul Kewirausahaan. Jakarta: HIkmah (PT Mizan Publika).

Syarat dan Prosedur Pendirian Koperasi di Indonesia. https://smartlegal.id/pendirianusaha/pendirian-koperasi/2019/04/26/syarat-dan-prosedur-pendirian-koperasi/ diakses pada: 30 Desember 2020

Ward, John, Peppard, Joe. (2002). Strategic Planning for Information System. 3rd Edition. John Willey \& Sons, Buffins Lane, Chichester 